\title{
DAYA HAMBAT EKSTRAK LIDAH BUAYA (Aloe barbadensis Miller) TERHADAP PERTUMBUHAN BAKTERI Staphylococcus aureus SECARA IN VITRO
}

\section{(INHIBITORY POWEROF ALOE VERA EXTRACT (Aloe Barbadensis Miller) AGAINST BACTERIA GROWTH Staphylococcus Aureus IN VITRO)}

\author{
Pramesti-Indah-Prabasari, ${ }^{1}$., Sumarya, I M. ${ }^{2}$, Juliasih, N. K. A. ${ }^{2}$ \\ ${ }^{1}$ Program Biologi, Fakultas MIPA, Universitas Hindu Indonesia \\ ${ }^{2}$ Fakultas MIPA Universitas Hindu Indonesia Denpasar Bali-Indonesia \\ E-mail : mez_prabha@gmail.com
}

\begin{abstract}
Aloe vera (Aloe barbadensis Miller) contains anthraquinone compounds, flavonoids and saponins which are thought to have antibacterial effects so as to inhibit bacterial growth. The purpose of the study was to determine the inhibitory power of Aloe barbadensis Miller on the growth of Staphylococcus aureus bacteria. The pure experimental study was conducted with The Randomized Posttest Only Control Group Design using six (6) treatments, namely aloe vera extract with a concentration of $25 \%$, $50 \%, 75 \%, 100 \%$, Chloramphenicol $30 \mathrm{mcg}$ antibiotics as a positive control, and sterile aquadest as a control negative for Staphylococcus aureus bacteria grown on Mueller Hinton media. After being treated, it was incubated for 24 hours and measured its inhibitory power. The growth inhibition data of Staphylococcus aureus bacteria in the form of inhibition zone diameter was analyzed statistically by Kruskal Wallis test, at the level of confidence $\alpha=0.05$. The results showed that the average inhibitory effect of Aloe vera extract on the growth of Staphylococcus aureus bacteria in concentrations of $25 \%, 50 \%, 75 \%$ and $100 \%$ were $0 \pm 0 \mathrm{~mm} ; 7.125 \pm 0.1250 \mathrm{~mm} ; 8.375 \pm 0.23936$ $\mathrm{mm}$; and $9.0 \pm 0.40825 \mathrm{~mm}$. Based on the results of the study concluded that aloe vera extract can inhibit the growth of Staphylococcus aureus bacteria. The higher the concentration of Aloe vera extract the greater the inhibitory effect on the growth of Staphylococcus aureus bacteria.
\end{abstract}

Keywords: Aloe vera, Staphylococcus aureus, inhibitory power

\begin{abstract}
ABSTRAK
Lidah buaya (Aloe barbadensis Miller) mengandung senyawa antrakuinon, flavonoid dan saponin yang diduga mempunyai efek sebagai antibakteri sehingga mampu menghambat pertumbuhan bakteri. Tujuan penelitian adalah untuk mengetahui daya hambat ekstrak lidah buaya (Aloe barbadensis Miller) terhadap pertumbuhan bakteri Staphylococcus aureus.Penelitian eksperimen murni dilakukan dengan rancangan The Randomized Posttest Only Control Group Design menggunakan enam (6) perlakuan yaitu ekstrak lidah buaya dengan konsentrasi 25\%, 50\%, 75\%, 100\%,
\end{abstract}


antibiotik Chloramphenicol $30 \mathrm{mcg}$ sebagai kontrol positif, dan aquadest steril sebagai kontrol negative terhadap bakteri Staphylococcus aureus yang ditumbuhkan pada media Mueller Hinton. Setelah diberi perlakuan diinkubasi selama 24 jam dan diukur daya hambatnya. Data daya hambatpertumbuhan bakteri Staphylococcus aureus berupa diameter zone hambat di analisis secara statistik dengan ujiKruskal Wallis, pada taraf kepercayaan $\alpha=0,05$. Hasil penelitian menunjukkan bahwa rata-rata daya hambat ekstrak lidah buaya terhadap pertumbuhan bakteri Staphylococcus aureus secara berturut-turut pada konsentrasi $25 \%, 50 \%, 75 \%$, dan $100 \%$ adalah0 $\pm 0 \mathrm{~mm} ; 7,125 \pm$ $0,1250 \mathrm{~mm} ; 8,375 \pm 0,23936 \mathrm{~mm}$; dan 9,0 $\pm 0,40825 \mathrm{~mm}$. Berdasarkan hasil penelitiandisimpulkan bahwa ekstrak lidah buaya dapat menghambat pertumbuhan bakteri Staphylococcus aureus. Semakin tinggi konsentrasi ekstrak lidah buaya semakin besardaya hambatnya terhadap pertumbuhan bakteri Staphylococcus aureus.

Kata kunci : Lidah buaya, Staphylococcus aureus, daya hambat

\section{PENDAHULUAN}

Aloe merupakan tanaman family Liliaceae yang mempunyai spesies yang berbeda. Di antara spesies ini hanya satu jenis yang lazim digunakan sebagai tanaman obat sejak ribuan tahun yang lalu, yaitu Aloe vera atau yang sering disebut dengan nama lidah buaya. Lidah buaya merupakan tanaman yang fungsional karena semua bagian dari tanaman ini dapat dimanfaatkan, baik untuk perawatan tubuh maupun untuk mengobati berbagai penyakit. Berdasarkan hasil penelitian, lidah buaya dapat berfungsi sebagai antiinflamasi, anti jamur, antibakteri dan regenerasi sel (Furnawanthi, 2007).

Senyawa kimia yang berkhasiat obat dari tumbuhan merupakan hasil dari metabolit sekunder, yaitu hasil samping proses metabolisme, seperti alkaloid, terpenoid, flavonoid, fenolik, kumarin, kuinon, lignin, dan glikosida. Fungsi metabolit sekunder pada organisme sangat bervariasi, antara lain sebagai pelindung atau pertahanan diri terhadap serangan atau gangguan yang ada disekitarnya dan sebagai antibiotik (Tamin dan Arbain, 1995).

Kandungan zat aktif lidah buaya yang sudah teridentifikasi antara lain Saponin, Sterol, Acemannan, Antrakuinon (Purbaya, 2003; Furnawanthi, 2004). Selain itu, lidah buaya memiliki kandungan flavonoid, jenis quercetin dan kaempferol yang diharapkan dapat menghambat pertumbuhan bakteri. Kaempferol memiliki aktivitas anti bakteri dengan mendenaturasi protein sel bakteri dan 
merusak membran sel tanpa dapat diperbaiki lagi. Sedangkan quercetin memiliki aktivitas meningkatkan permebilitas protein porin bakteri terhadap flavonoid lain. Adanya senyawa flavonoid, dimana secara farmakologi senyawa flavonoid berfungsi sebagai zat anti inflamasi, anti oksidan, analgesik dan anti bakteri (Sultana dan Anwar, 2008).

Penyakit infeksi akibat bakteri merupakan penyakit yang sudah sering dijumpai di berbagai negara berkembang seperti Indonesia. Penyakit ini juga bisa disebut penyakit rakyat karena menyerang hampir seluruh lapisan masyarakat. Di antara penyakit infeksi yang disebabkan berbagai bakteri, yang masih menjadi perhatian yaitu infeksi bakteri Staphylococcus aureus (Putra, 2011). Staphylococcus aureus merupakan bakteri coccus gram positif, dengan bentuk bergerombol dan tidak teratur seperti anggur. Staphylococcus aureus tumbuh pada media cair dan padat seperti NA (Nutrient Agar) dan BAP (Blood Agar Plate) dan aktif melakukan metabolisme, mampu memfermentasikan karbohidrat menghasilkan bermacam-macam pigmen seperti putih dan kuning (Dowshen, et al., 2002).

Staphylococcus aureus dapat ditemukan pada permukaan kulit sebagai flora normal, terutama di sekitar hidung, mulut, alat kelamin, dan sekitar anus. Dapat menyebabkan infeksi pada luka, biasanya berupa abses yang merupakan kumpulan nanah atau cairan dalam jaringan yang disebabkan oleh infeksi. Infeksi Staphylococcus aureus dapat menular selama ada nanah yang keluar dari lesi. Selain itu jari jemari juga dapat membawa infeksi Staphylococcus aureus dari satu bagian tubuh yang luka atau robek (Dowshen, et al.,2002).

Penggunaan antibiotik untuk mengobati penyakit infeksi, sering menyebabkan terjadinya resistensi bakteri terhadap zat antibiotik. Dewasa ini masyarakat di Indonesia banyak yang memanfaatkan obat herbal atau obatobatan tradisional berbahan dasar dari tanaman obat, sebagai pengobatan alternatif. Salah satunya adalah pengobatan penyakit infeksi yaitu sebagai antibiotik alami yang terkandung di dalam tanaman khususnya tanaman Aloe vera (Depkes, 2007).

Beberapa penelitian sebelumnya menyatakan bahwa khasiat dan manfaat 


\section{WIDYA BIOLOI}

E ISSN :

lidah buaya (Aloe vera) terhadap

media

pertumbuhan

bakteri pengobatan, khususnya pengobatan luka Staphylococcus aureus, biakan bakteri yaitu oleh C.E.Collins, 1934 dari Amerika Serikat dan James Fulto, MD (dermatologist) dari Newport Beach, California, AS yang dilakukan dengan cara mengoleskan lidah buaya (Aloe vera) pada luka borok dan luka operasi. Hasil yang didapat menyatakan bahwa pengobatan luka tersebut lebih cepat sembuhnya (Furnawanthi, 2002).

Sesuai dengan uraian diatas maka diduga kuat ekstrak lidah buaya memiliki aktivitas antibakteri terhadap bakteri Staphylococcus aureus. Untuk itu perlu dilakukan penelitian tentang antivitas antibakteri dan kekuatannya dengan menentukan daya hambat dan kekuatannya terhadap pertumbuhan bakteri staphylococcus aureus.

\section{BAHAN DAN METODE}

\section{Bahan}

Bahan-bahan yang digunakan adalah ekstrak lidah buaya yang berasal dari lidah buaya jenis Aloe barbadensis Miller berumur 6 bulan, Etanol 96\%, kertas saring, aquadest steril, disk antibiotik Chloramphenicol $30 \mathrm{mcg}$, kertas cakram/disk blank, media Mueller Hinton, media Nutrient Agar sebagai

\section{Metode \\ Pembuatan ekstraksi lidah buaya}

Dua puluh $\mathrm{kg}$ lidah buaya segar berwarna hijau, dicuci bersih dengan air mengalir kemudian dipotong-potong tipis, dan dikering anginkan selama kurang lebih 2-3 hari. Potonganpotongan kering dihaluskan dengan blender hingga menjadi serbuk halus dan dimaserasi dengan etanol $96 \%$ pada temperature kamar selama 24 jam. Filtratnya disaring dan dievaporasi hingga semua filtratnya menguap dan didapatkan ekstrak kental berwarna hijau kehitaman sebanyak 13,3 gram.

\section{Pembuatan media Mueller Hinton}

Sebanyak 13,3 g bubuk media Mueller Hintondilarutkan dalam $350 \mathrm{ml}$ aquadest dan dipanaskan hingga larut sempurna.Sterilisasi selama 15 menitkemudian tuangkan ke dalam petridish dan diamkan hingga beku dan simpan dalam keadaan terbalik. 


\section{WIDYA BIOLOI}

E ISSN :

Uji daya hambat secara difusi cakram disk

Sebanyak 1-3 koloni inokulum bakteri Staphylococcus aureus yang sama diambil dan disuspensikan ke dalam tabung yang berisi $5 \mathrm{ml}$ larutan $\mathrm{NaCl}$ fisiologis $0,85 \%$ dan dibandingkan kekeruhannya dengan standard kekeruhan Mc. Farland 0,5\%. Suspensi bakteri ditanam secara merata di permukaan media Mueller Hintondalam cawan petri kemudian tutup dan didiamkan selama 5-15 menit. Kertas cakram / disk blank yang sudah direndamdalam ekstrak lidah buaya masing-masing konsentrasi 25\%, 50\%, $75 \%$ dan $100 \%$ sampai jenuh, kertas disk blank yang direndam dalam $5 \mathrm{ml}$ aquadest steril, dan disk antibiotik Chloramphenicol $30 \mathrm{mcg}$ diletakkan pada permukaan Mueller Hinton dengan sedikit ditekan menggunakan pinset agar melekat sempurna.Jarak antara cakram disk yang satu dengan cakram disk lainnya minimal $15 \mathrm{~mm}$ untuk memudahkan pembacaan. Selanjutnya diinkubasi pada suhu $35-37^{\circ} \mathrm{C}$ selama 18-24 jam dalam posisi cawan petri yang terbalik. Kemudian diukur diameter zona hambat pertumbuhan bakteri Staphylococcus aureusdengan jangka sorong yang berupa daerah jernih disekitar kertas cakram (dalam satuan $\mathrm{mm})$.

Penelitian eksperimen murni (True Experimental) menggunakan rancangan The Randomized Posttest Only Control Group Design dilakukan dengan memberikan enam (6) kelompok perlakuan $(n=4)$ masing-masing berupa cakram diskberisi ekstrak lidah buaya dengan konsentrasi 25\% (P1), 50\% (P2), $75 \%$ (P3), 100\% (P4), cakram disk antibiotik Chloramphenicol $30 \mathrm{mcg}$ sebagai kontrol positif $(\mathrm{K}+)$, dan cakram disk berisi aquadest steril sebagai kontrol negative (K-) terhadap Subjek bakteri Staphylococcus aureus.Setelah perlakuan diukur daya hambatnya terhadap pertumbuhan bakteri Staphylococcus aureus.

Data daya hambat ekstrak lidah buaya terhadap pertumbuhan bakteri Staphylococcus aureus berupa diameter zone hambat dianalisis secara statistikdengan uji Kruskal Wallisyang dilanjutkan dengan uji U-Mann Whitney pada taraf kepercayaan $95 \%(\alpha=0,05)$. Kriteria daya hambat ekstrak lidah buaya terhadappertumbuhan bakteri Staphylococcus aureus dianalisis secara komparasi yaitu dengan 
membandingkan diameter zone hambat terhadap tabel keiteria zone hambat menurut Davis dan Stout (1971).

\section{HASIL}

Dari proses ekstraksi secara maserasi $20 \mathrm{~kg}$ lidah buaya dengan pelarut etanol $96 \%$ pada temperatur kamarselama 24jam, diperoleh hasil ekstrak lidah buaya berupa ekstrak kental

berwarna

hijau kehitaman sebanyak 13,3 gram.

Hasil eksperimenmenunjukkan bahwa rerata \pm SD daya hambat ekstrak lidah buaya terhadap pertumbuhan bakteri Staphylococcus aureus pada kelompok perlakuan $\mathrm{K}-, \mathrm{K}+, \mathrm{P} 1, \mathrm{P} 2$, P3, dan P4 adalah seperti disajikan pada tabel 4.1 berikut.

Tabel 4.1Daya Hambat Ekstrak Lidah Buaya terhadap Pertumbuhan BakteriStaphylococcus aureus

\begin{tabular}{ccc}
\hline Kelompok Perlakuan & $\begin{array}{c}\text { Rerata } \pm \begin{array}{c}\text { SD Daya Hambat } \\
(\mathrm{mm})\end{array} \\
\text { K- }\end{array}$ & Kriteria Zona Hambat \\
K+ & $0 \pm 0^{\mathrm{a}}$ & Lemah \\
P1 & $24,750 \pm 0,5000^{\mathrm{b}}$ & Sangat kuat \\
P2 & $0 \pm 0^{\mathrm{a}}$ & Lemah \\
P3 & $7,125 \pm 0,1250^{\mathrm{c}}$ & Sedang \\
P4 & $8,375 \pm 0,23936^{\mathrm{d}}$ & Sedang \\
\hline
\end{tabular}

\section{Catatan:}

1. Rerata dengan huruf yang sama pada kolom yang sama menunjukkan perbedaan yang tidak signifikan $(\mathrm{p}>0,05)$

2. Rerata dengan huruf yang berbeda pada kolom yang sama menunjukkan perbedaan yang signifikan $(\mathrm{p}<0,05)$

3. $\mathrm{K}-=$ kontrol negative, $\mathrm{K}+=$ kontrol positif, $\mathrm{P} 1, \mathrm{P} 2, \mathrm{P} 3$ dan $\mathrm{P} 4$ secara berturut-turut = perlakuan dengan ekstrak lidah buaya konsentrasi $25 \%, 50 \%, 75 \%$ dan $100 \%$.

Hasil eksperimen (table 4.1) pertumbuhan bakteri Staphylococcus menunjukkan bahwa ekstrak lidah buaya aureus dengan rerata daya hambat secara pada konsentrasi $25 \%$ belum dapat menghambat pertumbuhan bakteri berturut-turut adalah $7,125 \pm 0,1250$ Staphylococcus aureus karena rerata $\mathrm{mm}, 8,375 \pm 0,23936 \mathrm{~mm}$ dan $9,000 \pm$ daya hambatnya masih $0 \pm 0 \mathrm{~mm}$. 0,40825 $\mathrm{mm}$, berbeda secara signifikan Sedangkan pada konsentrasi $50 \%, 75 \%$ $(\mathrm{p}<0,05)$ antara rerata pada konsentrasi dan $100 \%$ baru dapat menghambat $50 \%$ dengan $75 \%$ dan $100 \%$. Berbeda secara tidak signifikan $(p>0,05)$ antara 
WIDYA BIOLOI

E ISSN : rerata pada konsentrasi $75 \%$ dengan $100 \%$.Semakin tinggi konsentrasi ekstrak lidah buaya, semakin tinggi daya hambatnya terhadap pertumbuhan bakteri Staphylococcus aureus. Daya hambat ekstrak lidah buaya terhadap pertumbuhn bakteri Staphylococcus aureus adalah termasuk dalam katagori sedang.

\section{PEMBAHASAN}

Ekstrak lidah buaya yang diperoleh melalui metode ekstraksi secara maserasi menggunakan pelarut etanol $96 \%$ berupa ekstrak kental berwarna hijau kehitaman, diduga mengandung senyawa aktif anti bakteri seperti flavonoid, saponin, kompleks antrakuinon antara lain aloe-emodin, aloin, barbaloin yang terdapat dalam lidah buaya. Hal ini sesuai dengan penelitian Natsir (2013).

Hasil penelitian menunjukkan bahwa daya hambat ekstrak lidah buaya terhadap pertumbuhan bakteri Staphylococcus aureus pada kelompok P1 adalah 0 (tidak terbentuk zona hambat) karena pada konsentrasi $25 \%$ tidak cukup untuk menghambat pertumbuhan bakteri Staphylococcus aureus. Hal ini bisa disebabkan karena kurangnya jumlah senyawa aktif antibakteri dari ekstrak lidah buaya. Selanjutnya pada kelompok P2 menghasilkan rerata daya hambat sebesar 7,125 $\mathrm{mm} \pm 0,2500$, kelompok P3 menghasilkan rerata daya hambat sebesar 8,375 $\mathrm{mm} \pm 0,4787$, dan pada kelompok P4 menghasilkan rerata daya hambat sebesar $9 \mathrm{~mm} \pm 0,8165$. Daya hambat tersebut menunjukkan semakin tinggi konsentrasi ekstrak lidah buaya maka semakin besar daya hambat terhadap bakteri Staphylococcus aureus (Tabel 4.1)

Ekstrak lidah buaya mempunyai kemampuan menghambat pertumbuhan bakteri Staphylococcus aureus karena menurut Hartanto dan Lubis (2002) bahwa lidah buaya mengandung zat antibakteri berupa saponin, flavonoid, dan antrakuinon yang mampu menghambat pertumbuhan bakteri Staphylococcus aureus. Mekanisme antibakteri antrakuinon yakni dengan menghambat sintesis protein dan sintesis asam nukleat bakteri melalui berikatan dengan asam nukleat dan membentuk suatu kompleks yang mengganggu fungsi dari cetakan DNA sehingga sintesis RNA dan protein bakteri menjadi terhambat (Chang dan But, 2001). Senyawa antrakuinon dalam lidah 


\section{WIDYA BIOLOI}

E ISSN :

buaya yang dapat menghambat sintesis protein dan sintesis asam nukleat meliputi aloin A, aloin $B$, barbaloin, aloinoside $A / B$, aloenin $B$, aloe-emodin8-O-glucoside (El-Sayed et al., 2016).

Kadar aloe-emodin dan aloin yang terkandung dalam lidah buaya masing-masing mencapai 8,3 dan 76,1 $\mu \mathrm{mol} / \mathrm{g}$ (Chiang et al., 2012). Aloeemodin dan aloin yang berhasil diisolasi dari lidah buaya terbukti memiliki aktivitas antibakteri terhadap bakteri Staphylococcus aureus. Aloe-emodin dan aloin memiliki aktivitas antibakteri dengan spektrum yang luas karena selain dapat menghambat Staphylococcus aureus dapat pula menghambat bakteri Gram Negatif seperti Escherichia coli dan Shigella sonnei.

Pandey and Mishra (2010) menyatakan antrakuinon memiliki struktur yang analog dengan tetrasiklin. Antrakuinon memiliki 3 cincin sedangkan tetrasiklin memiliki 4 cincin pada strukturnya. Tetrasiklin bersifat bakteriostatik dan menghambat sintesis protein bakteri dengan berikatan pada sisi A ( sisi yang berikatan dengan tRNA) di subunit $30 \mathrm{~S}$ ribosom. Ikatan tersebut menyebabkan kesalahan pembacaan antikodon dan kodon sehingga proses sintesis protein terganggu (Siswandono dan Soekarjo, 2008 ; Doughetry dan Pucci, 2012).

Fenol dan flavonoid juga diketahui memiliki aktivitas antibakteri dengan cara merusak permeabilitas dinding sel bakteri (Sharita et al., 2015). Senyawa fenolik yang terkandung dalam lidah buaya meliputi coumaric acid derivates, malonyl-3,4-Odicaffeoylquinic acid, caffeoyl quinic acid hexoside, 3-O-caffeoyl-5-Ocoumaroylquinic acid sedangkan senyawa flavonoid meliputi luteolin-6,8$\mathrm{C}$-diglucoside (lucenin II), luteolin-Oxylosylglucoside malonylated, apigenin6,8-C-diglucoside (vicenin II), luteolin8-C-glucoside (orientin), dan luteolin-6C-g;ucoside (isoorientin) (El-Sayed et al.,2016).

Senyawa antrakuinondapat menyebabkanprotein bakteri menjadi inaktif dan kehilangan fungsinya, sedangkan saponindapatmelarutkan lipid pada membran sel bakteri akibatnya dapat menurunkan tegangan lipid,permeabilitas sel berubah, fungsi sel bakteri menjadi tidak normal, dan sel bakteri lisis danmati. Flavonoid sebagai metabolit sekunder adalah senyawa fenol 
WIDYA BIOLOI

E ISSN :

berfungsi sebagai anti inflamasi, anti mikroba, dan anti oksidan (Natsir, 2013)

Daya hambat ekstrak lidah buaya dengan konsentrasi tertinggi (100\%) dalam penelitian ini hanya mampu menghambat pertumbuhan bakteri Staphylococcus aureus dengan rerata daya hambat sebesar $9 \mathrm{~mm}$ termasuk kategori sedang. Hal ini menunjukkan bahwa kemampuan daya hambat ekstrak lidah buaya tersebut masih dibawah kemampuan Chloramphenicol $30 \mathrm{mcg}$ (kontrol positif) dengan kategori sensitif.

Rerata daya hambat ekstrak Lidah Buaya pada konsentrasi 50\%, $75 \%$, dan $100 \%$ dibandingkan dengan kriteria zona hambat tergolong sedang. Adapun beberapa faktor yang dapat mempengaruhi ukuran zona hambat pada metode difusi cakram yaitu : kepadatan inokulum, waktu dari penggunaan cakram, suhu inkubasi, ukuran petri, kedalaman medium agar, pemberian jarak pada cakram antibiotika, dan komposisi medium (Syahidan, 2009).

\section{SIMPULAN}

Berdasarkan hasil penelitian dan pembahasan, disimpulkan bahwa Ekstrak lidah buaya pada konsentrasi $50 \%$, $75 \%$, dan $100 \%$ memiliki daya hambat terhadap pertumbuhan bakteri
Staphylococcus aureus dengan rerata zona hambat secara berturut-turut 7,125 $\mathrm{mm} ; 8,375 \mathrm{~mm}$; dan $9 \mathrm{~mm}$ yang tergolongke dalam kategori sedang.Semakin tinggi konsentrasi ekstrak lidah buaya semakin besar daya hambatnya terhadap pertumbuhan bakteri Staphylococcus aureus.

\section{DAFTAR PUSTAKA}

Chang, H.M., and But, P.P.H. 2001. Pharmacology and Applications of Chinese Materia Medica. Volume I. World Scientific Publishing, Singapore. 70-71

Chiang, H.M., Lin, Y.T., Hsiao, P.L., Su, Y.H., Tsao, H.T., Wen, K.C. 2012. Determination of marked components aloin and aloe emodin in Aloe vera before and after hydrolysis. JFDA. 20(3): 646-652.

Davis, W.W. and Stout, T.R. 1971. Disc plate method of microbiological antibiotic assay. I. Factors influencing variability and error. Applied Microbiol. 22: 659-665.

Depkes. 2007. Penggunaan antibiotik aloe vera untuk menghambat bakteri Staphylococcus aureus., available at: http://wordpress.com/ Penggunaan-antibiotik-aloeverauntuk-menghambatbakteri.aureus. html (diakses 6 Oktober 2017)

Doughetry, T.J., and Pucci, M.J. 2012. Antibiotic Discovery and Development. Springer, New York. 151 
WIDYA BIOLOI E ISSN :

Dowshen, D., and Parish. 2002. Staphylococcus aureus. Jurnal Appl Microbiologi 86 : 985-990

El-Sayed, A.M., Ezzat, S.M., El-Naggar, M.M., El-Hawary, S.S. 2016. In Vivo diabetic wound healing effect and hpcl-dad-esi-ms/ms profiling of the methanol extracts of eight Aloe species. Rev.Bras.Farmacogn. 26:352-362

Furnawanthi, I. 2002. Khasiat dan Manfaat Lidah Buaya. Agro Media Pustaka. Jakarta.

Furnawanthi, I. 2004. Khasiat dan Manfaat Lidah Buaya Si Tanaman Ajaib. Agro Media Pustaka. Jakarta. Hal 1-21.

Furnawanthi, I. 2007. Khasiat dan manfaat lidah buaya si tanaman ajaib. Edisi 8. Jakarta selatan: PT. AgroMedia Pustaka. hal.1-29.

Hartanto, E.S. dan Lubis, E.H.2002. Pengolahan Minuman Sari Lidah Buaya (Aloevera linn.). Warta IHP/J. Agro-Based Industry.

Natsir, N.A., 2013. Pengaruh Ekstrak Daun Lidah Buaya (Aloe vera) Sebagai Penghambat Pertumbuhan BakteriStaphylococcus aureus (jurnal). FMIPA Universitas Pattimura. Ambon

Pandey, R., and Mishra, A. 2010. Antibacterial activities of crude extract of Aloe barbadensis to clinically isolated bacterial pathogens. Appl Biochem Biotechnol. 160:1356-1361

Purbaya, J.R. 2003. Mengenal dan Memanfaatkan Khasiat Aloe vera. cv Pionerjaya. Bandung. Hal 21165.

Putra, D. 2011. Pengaruh Ekstrak Lidah Buaya (Aloe vera) sebagai Antimikroba terhadap Bakteri Shigella dysentriae secara In vitro.available from: http://www.scribd.com/pengaruhekstrak-lidahbuaya(aloevera)sebagaiantimikroba terhadap-bakteri-shigelladysentriae-secara-invitro.html (diakses 7 Oktober 2017)

Siswandono, dan Soekardjo, B. 2008. Kimia Medisinal. Airlangga University Press, Surabaya.

Sultana, B. dan Anwar, F. 2008. Flavonoal (kaempferol, quercetin, merycetin) contents of Selected Fruits, Vegetables and Medicinal Plants. Food Chemistry. 108: 879884.

Syahidan. 2009. Penuntun Praktikum Pengetahuan Media dan Reagensia I. Politeknik Kesehatan Bengkulu. Bengkulu.

Tamin, $\mathrm{R}$ dan Arbain, D.1995. Biodiversity dan Survey Etnobotani. Makalah lokakarya Isolasi Senyawa Berkhasiat. Kerjasama HEDS -FMIPA Universitas ANDALAS. Padang. 